\title{
PENGENDALIAN INTERN TERHADAP SISTEM PEMUNGUTAN PAJAK REKLAME PADA BADAN PENDAPATAN PENGELOLAAN KEUANGAN DAN ASET DAERAH (BPPKAD) KABUPATEN TEMANGGUNG
}

\author{
Arin Nuraeni, Siti Mutmainah \\ Jurusan Akuntansi Program Studi Akuntansi Politeknik Negeri Semarang, \\ Jl. Prof. Sudarto, SH Tembalang Semarang 50275
}

\begin{abstract}
Good internal control is very important to achieve the main goals of a company, therefore the purpose of this Final Project is to know the application of internal control structure of advertisement tax collection system at Badan Pendapatan Pengelolaan Keuangan dan Aset Daerah (BPPKAD) Kabupaten Temanggung and to identify the conformity with the components control according to PP Nomor 60 Tahun 2008 about The Government Internal Control System. The data used are qualitative data, primary data, and secondary data. Data collection using questionnaire method, interview, observation, and literature study. The writing methods of this final project are description and exposition. The result of this Final Project shows that the application of internal control of advertisement tax collection system at BPPKAD Temanggung Regency has been run effectively and has been run in accordance with the design of components of Government Internal Control System (SPIP). In the component of control activities that is the separation of duties, there are still dual positions. To reduce the misuse of authority, BPPKAD Kabupaten Temanggung should add additional employees.
\end{abstract}

Keywords: Internal Control Structures, Advertisement Tax Collection System, The Governments Internal Control System

Abstrak: Pengendalian intern yang baik sangat penting untuk mencapai tujuan utama instansi, oleh karena itu tujuan penelitian ini adalah untuk mengetahui penerapan pengendalian intern terhadap sistem pemungutan pajak reklame yang dijalankan oleh Badan Pendapatan Pengelolaan Keuangan dan Aset Daerah (BPPKAD) Kabupaten Temanggung dan mengidentifikasi kesesuaian dengan komponen pengendalian menurut Peraturan Pemerintah Nomor 60 Tahun 2008 tentang Sistem Pengendalian Intern Pemerintah (SPIP). Data yang digunakan adalah data kualitatif, data primer, dan data sekunder. Pengumpulan data menggunakan metode kuesioner, wawancara, observasi, dan studi pustaka. Penulisan penelitian menggunakan metode deskripsi dan eksposisi. Hasil penelitian ini menunjukkan bahwa penerapan pengendalian intern sistem pemungutan pajak reklame di BPPKAD Kabupaten Temanggung telah berjalan efektif dan telah dijalankan sesuai dengan rancangan komponen Sistem Pengendalian Intern Pemerintah (SPIP). Pada komponen kegiatan pengendalian yaitu pemisahan tugas, masih terdapat rangkap jabatan. Untuk mengurangi adanya penyalahgunaan wewenang sebaiknya BPPKAD Kabupaten Temanggung melakukan penambahan pegawai.

Kata Kunci: Struktur Pengendalian Intern, Sistem Pemungutan Pajak Reklame, Sistem Pengendalian Intern Pemerintah 


\section{PENDAHULUAN}

Pajak adalah iuran rakyat kepada kas negara berdasarkan undang-undang (yang dapat dipaksakan) dengan tiada mendapat jasa timbal balik (kontraprestasi) yang langsung dapat ditunjukkan dan digunakan untuk membayar pengeluaran umum. Pajak terdiri dari pajak pusat dan pajak daerah. Pajak daerah merupakan salah satu sumber pendapatan daerah yang memiliki peran besar dalam meningkatkan pendapatan daerah dan digunakan untuk keperluan daerah bagi sebesar-besarnya kemakmuran rakyat.

Dasar hukum pemungutan pajak dan retribusi daerah adalah Undangundang Nomor 28 Tahun 2009 tentang Pajak Daerah dan Retribusi Daerah. Pajak daerah terdiri dari pajak provinsi dan pajak kabupaten atau kota. Salah satu dari jenis pajak kabupaten atau kota adalah pajak reklame. Berdasarkan Peraturan Daerah Kabupaten Temanggung Nomor 18 Tahun 2009 tentang Pajak Reklame, reklame adalah benda, alat, perbuatan, atau media yang menurut bentuk susunan dan corak ragamnya dirancang untuk tujuan komersial, memperkenalkan, menganjurkan, mempromosikan, atau untuk menarik perhatian umum terhadap barang, jasa, orang atau badan yang dapat dilihat, dibaca, didengar, dirasakan, dan atau dinikmati oleh umum.

Badan Pendapatan Pengelolaan Keuangan dan Aset Daerah (BPPKAD) Kabupaten Temanggung adalah instansi pemerintah yang bertanggung jawab atas penyusunan dan pelaksanaan kebijakan daerah di bidang pengelolaan keuangan dan aset daerah. Pajak reklame merupakan salah satu sumber pendapatan daerah terbesar bagi kabupaten Temanggung sehingga dibutuhkan pengendalian intern yang baik terhadap sistem pemungutan pajak reklame. Pengendalian intern yang baik diharapkan dapat memberikan kepastian kepada masyarakat bahwa pemungutan pajak reklame dilakukan dengan benar sesuai peraturan perundang-undangan yang berlaku.

Pada tanggal 28 Agustus 2008, pemerintah menerbitkan Peraturan Pemerintah Nomor 60 Tahun 2008 tentang Sistem Pengendalian Intern Pemerintah (SPIP). Sistem Pengendalian Intern Pemerintah (SPIP) merupakan sistem pengendalian yang diselenggarakan secara menyeluruh di lingkungan pemerintah pusat dan daerah. Peraturan pemerintah ini merupakan penjabaran dari pasal 55 ayat (4), pasal 58 ayat (1), dan pasal 58 ayat (2) Undang-undang Nomor 1 Tahun 2004 tentang Perbendaharaan Negara. Menteri atau pimpinan lembaga selaku pengguna anggaran atau pengguna barang memberikan pernyataan bahwa pengelolaan APBN telah diselenggarakan berdasarkan sistem pengendalian intern yang memadai dan akuntansi keuangan telah diselenggarakan sesuai dengan Standar Akuntansi Pemerintah (SAP). Dalam rangka meningkatkan kinerja, transparasi, dan akuntabilitas pengelolaan keuangan negara, presiden selaku kepala pemerintahan mengatur dan menyelenggarakan sistem pengendalian intern di lingkungan pemerintahan secara menyeluruh. Hal ini membuat peneliti ingin mengetahui dan mengidentifikasi lebih lanjut mengenai sistem pemungutan pajak reklame yang diterapkan di BPPKAD Kabupaten Temanggung apakah pelaksanaan sistem pemungutan pajak reklame saat ini telah sesuai dengan struktur pengendalian intern yang berlaku atau belum.

Pusdiklatwas Badan Pengawas Keuangan dan Pembangunan (2009), menyatakan bahwa Sistem Pengendalian Intern Pemerintah (SPIP) merupakan adopsi dari konsep pengendalian intern menurut The Committee of Sponsoring 
Organizations of the Treadway Commission (COSO) yang merincikan pengendalian intern ke dalam lima komponen yakni lingkungan pengendalian, penilaian risiko, kegiatan pengendalian, informasi dan komunikasi, serta pemantauan. Peraturan Pemerintah Nomor 60 Tahun 2008 mewajibkan menteri, kepala lembaga, gubernur, bupati, dan walikota untuk mengimplementasikan SPIP di lingkungannya dan menetapkan Badan Pengawas Keuangan dan Pembangunan (BPKP) sebagai pembina penyelenggaraan pengendalian intern pemerintah.

Pengendalian intern tidak hanya berfungsi sebagai pengawas dalam setiap aktivitas instansi namun juga berperan dalam menciptakan lingkungan kerja yang efektif dan efisien. Dengan adanya pengendalian intern, maka aktivitas instansi akan selalu terjaga dan tidak melanggar peraturan yang telah ditetapkan, berikut disajikan

a. bagaimana rancangan komponen pengendalian intern terhadap sistem pemungutan pajak reklame pada BPPKAD Kabupaten Temanggung?

b. bagaimana rancangan komponen pengendalian intern terhadap sistem pemungutan pajak reklame pada BPPKAD Kabupaten Temanggung tersebut dijalankan, apakah sudah sesuai dengan ketentuan pada Sistem Pengendalian Intern Pemerintah (SPIP) yang berlaku.

\section{METODE}

Sesuai dengan tujuan peenelitian di atas, maka penelitian ini menggunakan rancangan atau desaian penelitian deskriptif kualitatif dan analisis Eksposisi, sedangkan pengumpulan data dengan cara: kuesioner, wawancara, observasi, dan studi pustaka.

a. Kuesioner

Menurut Burhan Bungin (2013:130)

metode kuesioner berbentuk rangkaian atau kumpulan pertanyaan yang disusun secara sistematis dalam sebuah daftar pertanyaan, kemudian dikirim kepada responden untuk diisi. Kuesioner dalam penelitian ini berisi pertanyaan tentang rancangan komponen pengendalian intern terhadap sistem pemungutan pajak reklame pada BPPKAD Kabupaten Temanggung. Kuesioner ini digunakan untuk mengidentifkasi pemahaman pengendalian intern terhadap sistem pemungutan pajak reklame pada BPPKAD Kabupaten Temanggung.

b. Wawancara

Burhan Bungin (2013:133) mendiskripsikan metode wawancara sebagai suatu proses memperoleh keterangan untuk tujuan penelitian dengan cara tanya jawab sambil bertatap muka antara pewawancara dengan responden atau orang yang diwawancarai, dengan atau tanpa menggunakan pedoman (guide) wawancara. Wawancara yang dilakukan dalam penelitian ini adalah wawancara secara langsung kepada pegawai bidang pelayanan, penetapan pendapatan, dan penagihan tentang rancangan komponen pengendalian intern sistem pemungutan pajak reklame pada BPPKAD Kabupaten Temanggung.

c. Observasi

"Observasi atau pengamatan adalah kegiatan keseharian manusia dengan menggunakan pancaindra mata sebagai alat bantu utamanya selain pancaindra lainnya seperti telinga, penciuman, mulut, dan kulit." (Burhan Bungin, 2013:142). Pengumpulan data dengan observasi dilakukan dengan mengamati secara langsung terhadap proses pelaksanaan dan dokumen atau catatan yang digunakan dalam sistem pemungutan pajak reklame pada BPPKAD Kabupaten Temanggung. 
d. Studi Pustaka

Menurut Supardi (2005:62) studi pustaka adalah kegiatan membaca, mencermati, mengenali, dan mengurai bahan bacaan (pustaka). Data yang diperoleh dari studi pustaka adalah dengan membaca dan memahami jurnal, penelitian terdahulu, internet untuk mendapatkan informasi mengenai sistem pemungutan pajak reklame pada BPPKAD Kabupaten Temanggung.

\section{HASIL DAN PEMBAHASAN}

I. Sistem Pemungutan Pajak Reklame pada Badan Pendapatan Pengelolaan Keuangan dan Aset Daerah (BPPKAD) Kabupaten Temanggung

Berdasarkan hasil wawancara dan observasi yang dilakukan terhadap dokumen dan catatan, sistem pemungutan pajak reklame pada BPPKAD Kabupaten Temanggung terdiri dari 4 prosedur yaitu prosedur pendaftaran dan pendataan wajib pajak, prosedur penetapan pajak, prosedur pembukuan dan pelaporan pajak, dan prosedur penagihan pajak.

\section{Prosedur Pendaftaran dan}

Pendataan Wajib Pajak Reklame

Pendaftaran dan pendataan wajib pajak merupakan kegiatan penghimpunan data obyek pajak. Wajib pajak mendaftarkan penyelenggaraan reklame pada BPPKAD Kabupaten Temanggung dalam jangka waktu paling lama 30 (tiga puluh) hari setelah penyelenggaraan reklame untuk dikukuhkan dan diberi Nomor Pokok Wajib Pajak Daerah (NPWPD). Bagian yang terkait dalam prosedur ini antara lain sub bidang pelayanan, sub bidang perencanaan dan pendataan, dan sub bidang pengelolaan data. Dokumen dan catatan yang digunakan dalam prosedur ini adalah Surat Pemberitahuan Obyek Pajak Daerah (SPOPD) dan Kartu Nomor Pokok Wajib Pajak Daerah (NPWPD).

\section{Prosedur Penetapan Pajak Reklame}

Penetapan pajak merupakan kegiatan penghitungan besarnya pajak yang harus dibayar oleh wajib pajak dan menerbitkan Surat Ketetapan Pajak Daerah (SKPD) berdasarkan Surat Pemberitahuaan Obyek Pajak Daerah (SPOPD). Wajib pajak di bebankan tarif paling tinggi 25\% (dua puluh lima persen) sesuai ketentuan yang diatur dalam Peraturan Daerah Kabupaten Temanggung Nomor 18 Tahun 2009 tentang Pajak Reklame Pasal 5 mengenai tarif pajak reklame. Apabila pajak daerah tidak dibayarkan dalam jangka waktu 30 (tiga puluh) hari sejak diterbitkannya Surat Ketetapan Pajak Daerah (SKPD) diterima, dikenakan sanksi administrasi sebesar $2 \%$ (dua persen) per bulan dan ditagih dengan menerbitkan Surat Tagihan Pajak Daerah (STPD). Bagian yang terkait dalam prosedur ini antara lain sub bidang pelayanan, sub bidang perencanaan dan pendataan, sub bidang pengelolaan data, dan sub bidang penetapan pendapatan. Dokumen dan catatan yang digunakan dalam prosedur ini antara lain Surat Pemberitahuan Obyek Pajak Daerah (SPOPD), Surat Ketetapan Pajak Daerah (SKPD) dan Kartu Nomor Pokok Wajib Pajak Daerah (NPWPD).

\section{Prosedur Pembayaran dan Pelaporan Pajak Reklame}

Kegiatan pembukuan dan pelaporan merupakan kegiatan pembukuan terhadap penerimaan pajak daerah dan pendapatan lainnya. Dengan dilakukanya pembukuan tersebut petugas dapat menyusun target penerimaan dan mengevaluasi serta melaporkan realisasi penerimaan pajak. Bagian yang terkait dalam prosedur ini antara lain kas umum daerah, sub bidang pelayanan, bendahara penerimaan, sub bidang penetapan pendapatan, sub bidang pengelolaan data, sub bidang penagihan, dan sub bidang pengendalian. Dokumen dan catatan yang digunakan dalam prosedur ini adalah Surat Ketetapan Pajak Daerah (SKPD) dan Surat Tanda Setoran (STS).

\section{Prosedur Penagihan Pajak Reklame}


Kegiatan penagihan merupakan kegiatan penarikan pajak oleh petugas kepada wajib pajak yang sudah melebihi masa pajak dengan menggunakan Surat Tagihan Pajak Daerah (STPD) berdasarkan ketetapan pajak daerah. Bagian yang terkait dalam prosedur ini antara lain sub bidang pengendalian, sub bidang penagihan, kas umum daerah, bendahara penerimaan, sub bidang pelayanan, sub bidang penetapan pendapatan, dan sub bidang pengelolaan data. Dokumen dan catatan yang digunakan dalam prosedur ini adalah Surat Tagihan Pajak Daerah (STPD), Surat Tanda Setoran (STS), dan Surat Ketetapan Pajak Daerah (SKPD).

\section{Rancangan Komponen Pengendalian Intern Sistem Pemungutan Pajak Reklame pada Badan Pendapatan Pengelolaan Keuangan dan Aset Daerah (BPPKAD) Kabupaten Temanggung}

Berikut pembahasan lebih lanjut mengenai sistem pengendalian intern sistem pemungutan pajak reklame pada BPPKAD Kabupaten Temanggung berdasarkan lima rancangan komponen pengendalian yang diperoleh dari hasil jawaban kuesioner, hasil observasi, dan hasil wawancara.

\section{Lingkungan Pengendalian}

Lingkungan pengendalian merupakan landasan utama unsur pengendalian intern untuk menghasilkan suatu pengendalian yang efektif. Faktorfaktor yang membentuk lingkungan pengendalian adalah sebagai berikut:

a. Penegakan integritas dan nilai etika

Penegakan integritas dan nilai etika dapat dilihat dari adanya peraturan-peraturan yang berlaku di BPPKAD Kabupaten Temanggung baik tertulis maupun tidak tertulis mengenai standar etika. Dalam melaksanakan pemungutan pajak reklame, BPPKAD Kabupaten Temanggung berpedoman pada Peraturan Daerah Kabupaten Temanggung Nomor 18 Tahun 2009 tentang Pajak Reklame dan Peraturan Daerah Kabupaten Temanggung Nomor 33 Tahun 2011 tentang Penyelenggaraan Reklame. Apabila terdapat pegawai yang melakukan penyimpangan dan penyelewengan akan diberikan sanksi yang tegas.

Salah satu nilai etika pegawai yang diterapkan di BPPKAD Kabupaten Temanggung salah satunya adalah kedisiplinan. Pegawai diharapkan datang tepat waktu pukul 07.15 WIB dan pulang pukul 16.00 WIB untuk hari Senin s/d Kamis, sedangkan untuk hari Jumat sampai pukul 10.45 WIB. Selain itu, etika pelayanan kepada wajib pajak pada saat melapor dan membayar pajak sudah dilaksanakan dengan baik, cepat, ramah, dan jelas.

b. Komitmen terhadap kompetensi Komitmen terhadap kompetensi yang dilakukan di BPPKAD Kabupaten Temanggung dapat dilihat dari latar belakang pendidikan pegawai yaitu minimal D3 Perguruan Tinggi. Ini menunjukkan bahwa pelaksanaan pemungutan pajak reklame dilakukan oleh pegawai yang berkompeten. BPPKAD Kabupaten Temanggung juga memberikan kesempatan kepada seluruh pegawai untuk mengikuti bimbingan teknis atau pelatihan yang diadakan oleh lembaga, perguruan tinggi, maupun instansi yang berkaitan dengan pemungutan pajak daerah. BPPKAD Kabupaten Temanggung mendorong semua pegawai untuk berkompetensi dan menggali potensi diri masing-masing pegawai untuk menunjukkan 
keahlian dan kemampuannya demi terlaksananya tugas dengan baik.

c. Kepemimpinan yang kondusif Pada BPPKAD Kabupaten Temanggung pimpinan instansi maupun kepala bidang melakukan interaksi secara intensif dengan pegawai pada tingkatan yang lebih rendah sehingga komunikasi antara atasan dengan bawahan tetap terjaga. Hubungan antar pegawai terjalin dengan baik.

d. Pembentukan struktur organisasi yang sesuai dengan kebutuhan Struktur organisasi BPPKAD Kabupaten Temangung sudah menunjukkan pemisahan fungsi yang jelas mengenai tugas, wewenang, dan tanggung jawab dari masing-masing bidang. Pemisahan fungsi tersebut diperlukan agar setiap bidang dapat memahami tugas dan tanggung jawabnya serta memungkinkan adanya internal check antar bidang. Akan tetapi masih terdapat kekurangan sumber daya manusia yang mengakibatkan adanya rangkap jabatan. Sebagai contoh pegawai bidang pelayanan merangkap jabatan sebagai bendahara penerimaan, pegawai bidang pelayanan, pengelolaan data, dan penetapan pendapatan juga merangkap jabatan sebagai petugas penagihan.

e. Pendelegasian wewenang dan tanggung jawab yang tepat

Untuk memperlancar tugas pokok dan fungsi BPPKAD Kabupaten Temanggung, kepala bidang menerapkan pendelegasian wewenang dan tanggung jawab dengan cara memberikan wewenang kepada masing-masing sub bidang sesuai dengan tugas dan tanggung jawabnya terkait dengan pemungutan pajak reklame. Hal ini bertujuan agar lebih mudah dalam melaksanakan percapaian target kerja maupun pengawasannya.
Bidang yang terkait dengan pemungutan pajak reklame adalah bidang perencanaan pendataan dan pelayanan, bidang pengelolaan data dan penetapan pendapatan, seta bidang penagihan pengendalian dan pelaporan. Wewenang dan tanggung jawab masing-masing bidang tersebut antara lain:

1) Bidang Perencanaan, Pendataan, dan Pelayanan

Bertanggung jawab melayani wajib pajak yang ingin memenuhi kewajibannya dalam pembayaran pajak reklame dan melakukan perencanaan pendataan wajib pajak untuk mendapatkan basis data pendapatan daerah.

2) Bidang Pengelolaan Data dan Penetapan Pendapatan

Bertanggung jawab untuk menyusun, menyimpan, dan memelihara basis data objek pajak serta melakukan pembetulan dokumen. Selain itu juga bertugas menetapkan jumlah pajak reklame yang harus dibayar oleh wajib pajak dan menerbitkan dokumen penetapan pajak yaitu Surat Ketetapan Pajak Daerah (SKPD).

3) Bidang Penagihan, Pengendalian, dan Pelaporan Bertanggung jawab untuk melakukan penagihan pajak terutang dan menyusun laporan pendapatan daerah.

f. Penyusunan dan penerapan kebijakan yang sehat tentang pembinaan sumber daya manusia BPPKAD Kabupaten Temanggung telah menempatkan pegawai sesuai dengan golongan dan kompetensi pegawai. Perekrutan pegawai dilakukan melalui penyeleksian calon pegawai negeri sipil dan 2pemanfaatan tenaga outsourcing. Proses perekrutan pegawai diatur 
oleh Badan Kepegawaian Daearh (BKD). Untuk meningkatkan kompetensi pegawai, BPPKAD Kabupaten Temanggung memberikan kesempatan kepada seluruh pegawai untuk mengikuti bimbingan teknis atau pelatihan terkait pemungutan pajak daerah.

g. Perwujudan peran aparat pengawasan intern pemerintah yang efektif

Tugas pokok dan fungsi BPPKAD Kabupaten Temanggung adalah mengawasi pelaksanaan tugas sebagian urusan pemerintahan daerah dalam bidang pendapatan, pengelolaaan keuangan, dan aset daerah. Antara rencana dan pelaksanaan dipantau dengan sistem pengawasan yang melekat sehingga apabila terjadi penyimpangan bisa diketahui sedini mungkin.

h. Hubungan kerja yang baik dengan instansi pemerintah terkait

Dalam melaksanakan tugasnya, BPPKAD Kabupaten Temanggung juga banyak melakukan hubungan kerjasama dengan instansi pemerintah terkait dengan pemungutan pajak reklame dan berlangsung dengan baik. Contoh hubungan kerja BPPKAD Kabupaten Temanggung dengan instansi pemerintah terkait yaitu, kerjasama dengan Satuan Polisi Pamong Praja terkait dengan penertiban reklame, dan kerjasama dengan Dinas Pekerjaan Umum (DPU) terkait dengan permohonan izin penyelenggaraan reklame, dan kerjasama dengan programmer terkait dengan sistem informasi yang digunakan dalam pemungutan pajak reklame.

\section{Penilaian Risiko}

Penilaian risiko terdiri atas identifikasi risiko dan analisis risiko. Risiko tersebut muncul karena beberapa sebab diantarannya karena kesalahan sistem atau penyampaian informasi yang salah karena kesalahan pegawai itu sendiri (human error). BPPKAD Kabupaten Temanggung juga mempunyai strategi dalam mengidentifikasi dan menganalisis risiko sehingga instansi dapat meminimalisir risiko tersebut. Hasil identifikasi dan analisis risiko yang dilakukan oleh BPPKAD Kabupaten Temanggung terkait dengan sistem pemungutan pajak reklame, yaitu:

1. Keterlambatan pembayaran pajak. Untuk mengatasi risiko tersebut BPPKAD Kabupaten Temanggung menerapkan adanya sanksi berupa denda keterlambatan pembayaran pajak sesuai dengan peraturan perundang-undangan yang berlaku.

2. Penerimaan pendapatan daerah yang berasal dari pemungutan pajak reklame tidak mencapai target. Dalam praktiknya, BPPKAD Kabupaten Temanggung selama ini memungut pajak reklame berdasarkan kesadaran diri dari wajib pajak yang melapor. Masih banyak penyelenggaraan reklame dilapangan yang berizin tetapi tidak dipungut pajak reklame. Untuk mengatasi risiko tersebut, BPPKAD Kabupaten Temanggung sedang berupaya untuk melakukan kerja sama dengan Dinas Pekerjaan Umum (DPU) dan Satuan Polisi Penegak Perda untuk membuat suatu sistem yang terintegrasi sehingga semua reklame yang sudah memperoleh izin dari DPU, reklame yang sudah jatuh tempo, dan reklame yang sudah dengan yang belum membayar pajak bisa dipantau.

3. Kesalahan dalam proses penginputan data. Kesalahan penginputan data bisa disebabkan karena pegawai kurang teliti. Kebijakan dari BPPKAD Kabupaten Temanggung untuk mengatasi risiko tersebut adalah melakukan pengecekan ulang atas data yang di input dan adanya admin yang bertanggung jawab untuk melakukan pembetulan data 
dan dokumen sehingga apabila terjadi kesalahan dalam proses penginputan data bisa segera diatasi.

4. Penyelewengan pajak

Pajak merupakan harta yang paling rentan untuk diselewengkan karena tidak mempunyai tanda kepemilikan yang jelas. Untuk mengatasi penyelewengan penerimaan pajak daerah, kebijakan dari BPPKAD Kabupaten Temanggung adalah dengan memisahkan fungsi akuntansi dengan fungsi penerima kas. Segala bentuk penerimaan pendapatan daerah langsung masuk ke rekening kas umum daerah melalui bank jateng.

\section{Kegiatan Pengendalian}

Komponen-komponen yang terkait dalam kegiatan pengendalian sistem pemungutan pajak reklame pada BPPKAD Kabupaten Temanggung adalah sebagai berikut:

a. Review atas kinerja instansi pemerintah yang bersangkutan

Review yang dilakukan oleh BPPKAD Kabupaten Temanggung yaitu dengan menyelenggarakan monitoring dan evaluasi kinerja setiap triwulan pada semua bidang. Monitoring dan evaluasi ini bertujuan untuk mengevaluasi kinerja BPPKAD Kabupaten Temanggung agar semakin baik untuk perkembangan kedepannya dalam rangka mengoptimalkan pendapatan daerah dan menyamakan persepsi pegawai demi terwujudnya tujuan instansi. Review juga dilakukan oleh BPPKAD Kabupaten Temanggung dengan memantau penyelenggaraan reklame dilapangan.

b. Pembinaan sumber daya manusia Pembinaan sumber daya manusia yang dilakukan BPPKAD Kabupaten Temanggung yaitu dengan memberikan kesempatan kepada seluruh pegawai untuk mengikuti bimbingan teknis atau pelatihan yang diadakan oleh lembaga, perguruan tinggi, atau instansi yang berkaitan dengan pemungutan pajak daerah. BPPKAD Kabupaten Temanggung juga melakukan studi banding ke instansi daerah lain yang mempunyai prestasi kerja bagus terkait dengan pemungutan pajak daerah.

c. Pengendalian atas pengelolaan sistem informasi

Pengendalian atas pengelolaan sistem informasi pada BPPKAD Kabupaten Temanggung dalam pemungutan pajak reklame terdiri atas pengendalian umum dan pengendalian aplikasi. Pengendalian umum pada BPPKAD Kabupaten Temanggung yaitu adanya sistem informasi untuk sistem pemungutan pajak reklame yaitu semua kegiatan pemungutan terintregrasi ke dalam MAPATDA (Manajemen Pendapatan Daerah) dan hanya bisa diakses oleh pegawai BPPKAD Kabupaten Temanggung. Sedangkan untuk pengendalian aplikasi pada BPPKAD Kabupaten Temanggung dilakukan dengan adanya sistem otorisasi. Pengendalian terhadap keandalan pemrosesan data pada BPPKAD Kabupaten Temanggung semua dokumen selalu diotorisasi terlebih dahulu oleh pejabat yang berwenang.

d. Pengendalian fisik atas aset Dalam sebuah instansi, penjagaan aset sangat penting untuk dilakukan demi kelangsungan kegiatan operasional instansi. Cara yang paling tepat dalam penjagaan aset adalah dengan melakukan perlindungan fisik atas aset. Pengendalian fisik atas aset dilakukan untuk mengamankan dan melindungi aset instansi. Pengendalian fisik atas aset berupa barang yang dilakukan oleh 
BPPKAD Kabupaten Temanggung adalah dengan menginventaris aset yang dimiliki. Pengendalian fisik atas aset berupa kas dilakukan dengan cara disimpan langsung di rekening kas umum daerah melalui bank jateng. Bank jateng akan mengirimkan rekening koran setiap akhir bulan.

e. Penetapan dan review atas indikator dan ukuran kinerja

Setiap akhir tahun, BPPKAD Kabupaten Temanggung melakukan review atas realisasi penerimaan pendapatan daerah. Realisasi penerimaan tersebut digunakan sebagai dasar dalam menetapkan anggaran atau target penerimaan pendapatan untuk tahun selanjutnya.

f. Pemisahan fungsi

Dengan adanya struktur organisasi pembagian tugas, wewenang, dan tanggung jawab pegawai BPPKAD Kabupaten Temanggung terkait dengan sistem pemungutan pajak reklame berjalan dengan baik dan menunjukkan adanya pemisahan fungsi yang jelas. Pemisahan fungsi pada BPPKAD Kabupaten Temanggung adalah sebagai berikut:

1) Bidang Perencanaan, Pendataan, dan Pelayanan Bertanggung jawab melayani wajib pajak yang ingin memenuhi kewajibannya dalam pembayaran pajak reklame dan melakukan perencanaan pendataan wajib pajak.

2) Bidang Pengelolaan Data dan Penetapan Pendapatan

Bertanggung jawab untuk menyusun, menyimpan, dan memelihara basis data objek pajak serta melakukan pembetulan dokumen. Selain itu juga bertugas menetapkan jumlah pajak reklame yang harus dibayar oleh wajib pajak dan menerbitkan dokumen penetapan pajak yaitu Surat

Ketetapan Pajak Daerah (SKPD).

3) Bidang Penagihan, Pengendalian, dan Pelaporan

Bertanggung jawab untuk melakukan penagihan pajak terutang dan menyusun laporan pendapatan daerah.

Akan tetapi karena kurangnya sumber daya manusia, masih terdapat adanya rangkap jabatan. Sebagai contoh pegawai bidang pelayanan merangkap jabatan sebagai bendahara penerimaan, pegawai bidang pelayanan, pengelolaan data, dan penetapan pendapatan juga merangkap jabatan sebagai petugas penagihan.

g. Otorisasi atas transaksi dan kejadian penting

Otorisasi yang tepat sangat diperlukan untuk mendukung pengesahan dokumen-dokumen pada sistem pemungutan pajak reklame untuk mendukung pengendalian intern yang memadai. Sistem otorisasi bertujuan untuk menjaga dokumen agar tidak disalah gunakan. Prosedur otorisasi terhadap dokumen atas pemungutan pajak reklame pada BPPKAD Kabupaten Temanggung adalah sebagai berikut:

1) Surat Pemberitahuan Obyek Pajak Daerah (SPOPD) adalah surat yang digunakan oleh wajib pajak untuk melaporkan perhitungan dan/atau pembayaran pajak, obyek pajak dan/atau bukan obyek pajak, dan/atau harta dan kewajiban, menurut ketentuan peraturan perundang-undangan

perpajakan daerah. SPOPD harus di tandatangani terlebih dahulu oleh wajib pajak kemudian diserahkan kepada sub bidang pelayanan. Sub bidang pelayanan akan 
melakukan pemeriksaan berkas. Apabila berkas lengkap akan diotorisasi oleh kepala sub bidang pelayanan dan diserahkan kepada sub bidang perencanaan dan pendataan untuk proses selanjutnya. Akan tetapi, jika data tidak lengkap akan diserahkan kembali kepada wajib pajak.

2) Surat Ketetapan Pajak Daerah (SKPD) adalah surat ketetapan pajak yang menentukan besarnya jumlah pokok pajak yang terutang. Berdasarkan SPOPD yang diterima, sub bidang penetapan pendapatan melakukan perhitungan besarnya pajak yang harus dibayar oleh wajib pajak dan menerbitkan SKPD. SKPD tersebut, sebelum didistribusikan ke bagian-bagian yang terkait akan diotorisasi terlebih dahulu oleh kepala sub bidang penetapan pendapatan.

3) Surat Tanda Setoran (STS) adalah surat yang digunakan oleh wajib pajak untuk melakukan pembayaran atau penyetoran pajak yang terutang ke kas umum daerah atau tempat pembayaran lain yang ditunjuk oleh bupati. STS harus ditanda tangani oleh terlebih dahulu oleh wajib pajak kemudian diserahkan ke kas umum daerah melalui bank jateng dan diotorisasi sebagai bukti telah melakukan pembayaran pajak reklame.

h. Pencatatan yang akurat dan tepat waktu atas transaksi dan kejadian Sistem pencatatan akuntansi yang dilakukan oleh BPPKAD Kabupaten Temanggung sudah menggunakan accrual basis yaitu setiap transaksi dan kejadian diklasifikasikan dan dicatat sesuai dengan tanggal terjadinya transaksi. Sistem pencatatan dilakukan secara terkomputerisasi melalui aplikasi keuangan daerah. i. Pembatasan akses dan akuntabilitas atas sumber daya dan pencatatannya

Pimpinan instansi dalam hal ini adalah kepala BPPKAD Kabupaten Temanggung memberikan akses dan akuntabilitas atas sumber daya dan pencatatanya hanya kepada pegawai yang berkepentingan.

j. Dokumentasi yang baik atas sistem pengendalian intern serta transaksi dan kejadian penting BPPKAD Kabupaten Temanggung memiliki, mengelola, dan memelihara sistem pengendalian intern serta transaksi dan kejadian penting yang berkaitan dengan pemungutan pajak reklame dan didokumentasikan dengan baik dalam bentuk dokumen.

\section{Informasi dan Komunikasi}

Pelaksanaan informasi dan komunikasi oleh pegawai BPPKAD Kabupaten Temanggung telah dilakukan dengan baik. Sistem informasi yang diterapkan oleh BPPKAD Kabupaten Temanggung telah terkomputerisasi. Yaitu adanya sistem pengelolaan keuangan berbasis komputer berupa Manajemen Pendapatan Daerah (Mapatda). Mapatda adalah sistem yang dapat menunjang kinerja yang berhubungan dengan pendapatan daerah dan dapat melihat sampai sejauh mana pendapatan daerah itu tercapai. Komunikasi yang terjalin baik antara pimpinan instansi dengan pegawai pada tingkatan yang lebih rendah maupun antar sesama pegawai berjalan dengan baik. Sebelum jam kerja dimulai selalu ada briefing dan doa bersama yang dipimpin oleh pimpinan instansi atau kepala bidang. Pemberian informasi dan komunikasi juga tertuang pada setiap dokumen. Informasi dituangkan dalam bentuk otorisasi oleh kepala bidang. Untuk mendukung agar informasi dan komunikasi tersebut dapat tersampaikan dengan baik, maka diperlukan pengkomunikasian dan 
koordinasi yang baik kepada bidang yang terkait.

\section{Pemantauan}

Pemantauan dilakukan agar kegiatan yang dilakukan oleh instansi berjalan dengan baik, terarah, dan sesuai dengan kebijakan yang telah ditetapkan oleh instansi. Pemantauan yang dilakukan oleh BPPKAD Kabupaten Temanggung adalah sebagai berikut:

a. Pemantauan dilakukan oleh pimpinan instansi dengan adanya review dan evaluasi kinerja pegawai pada semua bidang setiap triwulan untuk memantau perkembangan kinerja BPPKAD Kabupaten Temanggung.

b. Pemantauan dilakukan kepala bidang yang dilakukan setiap hari untuk memantau proses pemungutan pajak reklame. Kepala bidang bidang ikut berpartisipasi dalam melakukan pemungutan dan penagihan pajak reklame dilapangan.

c. Pemantauan dilakukan oleh Badan Pengawas Keuangan dan Pembangunan (BPKP) selaku pihak yang berkewajiban melakukan pengawasan dan pemeriksaan untuk memantau perkembangan BPPKAD Kabupaten Temanggung serta memastikan pelaksanaan aktivitas setiap bagian terutama penerimaan pajak dilaksanakan sesuai dengan sistem dan prosedur yang berlaku.

d. Pengawasan dilakukan oleh auditor internal yaitu inspektorat kabupaten untuk mengevaluasi kinerja dan laporan keuangan daerah seluruh SKPD.

$\begin{array}{llr}\text { III. } & \text { Hasil } & \text { Identifikasi } \\ \text { Rancangan } & \text { Komponen } \\ \text { Pengendalian } & \text { Intern } \\ \text { Sistem Pemungutan Pajak } \\ \text { Reklame pada } & \text { Badan } \\ \text { Pendapatan } & \text { Pengelolaan } \\ \text { Keuangan dan Aset Daerah } \\ \text { (BPPKAD) } & \text { Kabupaten } \\ \text { Temanggung } & \text { dengan } \\ \text { Komponen } & \text { Sistem } \\ \text { Pengendalian } & \text { Intern } \\ \text { Pemerintah (SPIP) } & \end{array}$

Berikut adalah hasil identifikasi rancangan komponen pengendalian intern sistem pemungutan pajak reklame pada BPPKAD Kabupaten Temanggung dengan rancangan komponen pengendalian intern menurut Sistem Pengendalian Intern Pemerintah (SPIP) yang berlaku.

\begin{tabular}{|c|c|c|c|}
\hline No. & Komponen Pengendalian & $\begin{array}{c}\text { Sesuai/ } \\
\text { Tidak }\end{array}$ & Keterangan \\
\hline \multicolumn{4}{|c|}{ Lingkungan Pengendalian } \\
\hline 1. & $\begin{array}{l}\text { Penegakan integritas } \\
\text { dan nilai etika }\end{array}$ & Sesuai & $\begin{array}{l}\text { BPPKAD Kabupaten Temanggung telah } \\
\text { menetapkan kebijakan secara tertulis dan tidak } \\
\text { tertulis mengenai standar etika. Dalam pelaksanaan } \\
\text { pemungutan pajak reklame, BPPKAD telah } \\
\text { berpedoman pada peraturan daerah yang berlaku. }\end{array}$ \\
\hline 2. & $\begin{array}{l}\text { Komitmen } \quad \text { terhadap } \\
\text { kompetensi }\end{array}$ & Sesuai & $\begin{array}{l}\text { Adanya latar belakang pendidikan, adanya pelatihan } \\
\text { dan bimbingan teknis untuk pengembangan karir } \\
\text { pegawai, dan adanya orang-orang yang berkompeten } \\
\text { dalam pemungutan pajak reklame. }\end{array}$ \\
\hline 3. & $\begin{array}{l}\text { Kepemimpinan yang } \\
\text { kondusif }\end{array}$ & Sesuai & $\begin{array}{l}\text { Terjalinnya hubungan dan komunikasi yang baik } \\
\text { dan kondusif antara atasan dengan bawahan. }\end{array}$ \\
\hline 4. & $\begin{array}{l}\text { Pembentukan struktur } \\
\text { organisasi yang sesuai } \\
\text { dengan kebutuhan }\end{array}$ & Sesuai & $\begin{array}{l}\text { Struktur organisasi BPPKAD Kabupaten } \\
\text { menujukkan pemisahan fungsi yang jelas mengenai } \\
\text { tugas, wewenang, dan tanggung jawab dari masing- } \\
\text { masing bidang. Akan tetapi masih adanya } \\
\text { kekurangan sumber daya manusia yang } \\
\text { mengakibatkan adanya rangkap jabatan yang bisa }\end{array}$ \\
\hline
\end{tabular}




\begin{tabular}{|c|c|c|c|}
\hline & & & $\begin{array}{l}\text { berdampak pada penyalahgunaan tugas, wewenang, } \\
\text { dan tanggung jawab. }\end{array}$ \\
\hline 5. & $\begin{array}{l}\text { Pendelegasian } \\
\text { wewenang dan tanggung } \\
\text { jawab yang tepat }\end{array}$ & Sesuai & $\begin{array}{l}\text { Dalam setiap pendelegasian wewenang } \\
\text { dilaksanakan dengan memperhatikan bahwa } \\
\text { wewenang diberikan kepada pegawai yang tepat dan } \\
\text { adanya job description. }\end{array}$ \\
\hline 6. & $\begin{array}{lr}\text { Penyusunan } & \text { dan } \\
\text { penerapan kebijakan } \\
\text { yang sehat tentang } \\
\text { sumber daya manusia }\end{array}$ & Sesuai & $\begin{array}{l}\text { Adanya kegiatan seleksi proses perekrutan bagi } \\
\text { calon pegawai dan tenaga outsourcing dan adanya } \\
\text { pelatihan bagi pegawai. }\end{array}$ \\
\hline 7. & $\begin{array}{l}\text { Perwujudan peran } \\
\text { aparat pengawasan } \\
\text { intern pemerintah yang } \\
\text { efektif }\end{array}$ & Sesuai & $\begin{array}{l}\text { Adanya pengawasan dalam pelaksanaan tugas } \\
\text { untuk meminimalisir penyalahgunaan wewenang } \\
\text { dan tanggung jawab demi tercapainya visi, misi, dan } \\
\text { tujuan instansi. }\end{array}$ \\
\hline 8. & $\begin{array}{l}\text { Hubungan kerja yang } \\
\text { baik dengan instansi } \\
\text { pemerintah terkait }\end{array}$ & Sesuai & $\begin{array}{l}\text { Adanya hubungan kerjasama yang terjalin baik } \\
\text { dengan instansi pemerintah terkait. }\end{array}$ \\
\hline \multicolumn{2}{|c|}{ Penilaian Resiko } & Sesuai & $\begin{array}{l}\text { BPPKAD Kabupaten Temanggung telah } \\
\text { mengidentifkasi, mengelola, dan mengevaluasi risiko } \\
\text { sebagai contoh risiko keterlambatan pembayaran } \\
\text { pajak. Untuk mengatasi risiko tersebut BPPKAD } \\
\text { Kabupaten Temanggung menerapkan adanya denda } \\
\text { untuk keterlambatan pembayaran pajak sesuai } \\
\text { dengan peraturan perundang-undangan yang } \\
\text { berlaku. }\end{array}$ \\
\hline \multicolumn{4}{|c|}{ Kegiatan Pengendalian } \\
\hline 1. & $\begin{array}{l}\text { Review atas kinerja } \\
\text { instansi pemerintah } \\
\text { yang bersangkutan }\end{array}$ & Sesuai & Adany \\
\hline 2. & Ian sumber daya & Ses & $\begin{array}{l}\text { Adanya uraian jabatan, prosedur rekruitmen, dan } \\
\text { pelatihan untuk pengembangan karir pegawai. }\end{array}$ \\
\hline 3. & $\begin{array}{lr}\begin{array}{l}\text { Pengendalian } \\
\text { pengelolaan }\end{array} & \text { atas } \\
\text { informasi } & \text { sistem }\end{array}$ & Sesuai & $\begin{array}{l}\text { Adanya sistem informasi untuk merekam kegiatan } \\
\text { pemungutan pajak reklame dan adanya sistem } \\
\text { otorisasi untuk pengendalian terhadap valid atau } \\
\text { tidaknya pengelolaan data. }\end{array}$ \\
\hline 4. & $\begin{array}{l}\text { Pengendalian fisik atas } \\
\text { aset }\end{array}$ & Sesuai & $\begin{array}{l}\text { Adanya inventarisasi terhadap aset yang dimiliki } \\
\text { oleh BPPKAD Kabupaten Temanggung sebagi } \\
\text { bentuk perlindungan fisik atas aset. }\end{array}$ \\
\hline 5. & $\begin{array}{lr}\text { Penetapan dan review } \\
\text { atas indikator dan } \\
\text { ukuran kinerja }\end{array}$ & Sesuai & $\begin{array}{l}\text { Setiap akhir tahun, BPPKAD Kabupaten } \\
\text { Temanggung melakukan review atas realisasi } \\
\text { penerimaan pendapatan daerah dan dievaluasi. }\end{array}$ \\
\hline 6. & Pemisahan fungsi & Sesuai & $\begin{array}{l}\text { Penerapannya telah sesuai dengan SPIP. Akan } \\
\text { tetapi karena kurangnya sumber daya manusia, } \\
\text { sehingga masih terdapat adanya rangkap jabatan. } \\
\text { Sebagai contoh pegawai bidang pelayanan } \\
\text { merangkap jabatan sebagai bendahara penerimaan. }\end{array}$ \\
\hline 7. & $\begin{array}{l}\text { Otorisasi atas transaksi } \\
\text { dan kejadian yang } \\
\text { penting }\end{array}$ & Sesu & $\begin{array}{l}\text { Adanya penerapan sistem otorisasi oleh pejabat yang } \\
\text { berwenang dan pemberian nomor urut terhadap } \\
\text { dokumen sehingga dokumen tidak salah digunakan. }\end{array}$ \\
\hline 8. & $\begin{array}{l}\text { Pencatatan yang akurat } \\
\text { dan tepat waktu atas } \\
\text { transaksi dan kejadian }\end{array}$ & Sesuai & $\begin{array}{l}\text { BPPKAD Kabupaten Temanggung melakukan } \\
\text { pencatatan atas transaksi dan kejadian penting dan } \\
\text { sistem pencatatannya dilaksanakan dengan } \\
\text { terkomputerisasi. }\end{array}$ \\
\hline
\end{tabular}




\begin{tabular}{|c|l|l|l|}
\hline 9. & $\begin{array}{l}\text { Pembatasan akses atas } \\
\text { sumber daya dan } \\
\text { pencatatannya }\end{array}$ & Sesuai & $\begin{array}{l}\text { BPPKAD Kabupaten Temanggung memberikan } \\
\text { akses dan akuntabilitas atas sumber daya dan } \\
\text { pencatatanya hanya kepada pegawai yang } \\
\text { berkepentingan. }\end{array}$ \\
\hline 10. & $\begin{array}{l}\text { Akuntabilitas terhadap } \\
\text { sumber daya dan } \\
\text { pencatatannya }\end{array}$ & Sesuai & $\begin{array}{l}\text { BPPKAD Kabupaten Temanggung memberikan } \\
\text { akses dan akuntabilitas atas sumber daya dan } \\
\text { pencatatanya hanya kepada pegawai yang } \\
\text { berkepentingan. }\end{array}$ \\
\hline 11. & $\begin{array}{l}\text { Dokumentasi yang baik } \\
\text { atas sistem pengendalian } \\
\text { intern serta transaksi } \\
\text { dan kejadian penting }\end{array}$ & Sesuai & $\begin{array}{l}\text { BPPKAD Kabupaten Temanggung telah memiliki, } \\
\text { mengelola, dan memelihara transaksi dan kejadian } \\
\text { penting yang berkaitan dengan pemungutan pajak } \\
\text { reklame dan didokumentasikan dengan baik dalam } \\
\text { bentuk dokumen. }\end{array}$ \\
\hline Informasi dan Komunikasi & Sesuai & $\begin{array}{l}\text { Penerapannya telah sesuai dengan SPIP hal ini } \\
\text { dapat dilihat dengan adanya pertukaran informasi } \\
\text { melalui briefing pagi, pemberian informasi penting } \\
\text { sebelum aktivitas kerja dimulai, saling koordinasi } \\
\text { antar bidang, dan adanya sistem pengelolaan } \\
\text { pendapatan daerah berbasis komputer berupa } \\
\text { Manajemen Pendapatan Daerah (Mapatda) }\end{array}$ \\
\hline Pemantauan & Sesuai & $\begin{array}{l}\text { Pemantauan yang diterapkan oleh BPPKAD } \\
\text { Kabupaten Temanggung telah sesuai dengan SPIP } \\
\text { yang berlaku. Hal ini dapat dilihat dari adanya } \\
\text { pemantauan yang dilakukan oleh pimpinan instansi, } \\
\text { kepala bidang, Badan Pengawas Keuangan dan } \\
\text { Pembangunan (BPKP), dan Inspektorat Kabupaten. }\end{array}$ \\
\hline
\end{tabular}

\section{Simpulan}

Berdasarkan pembahasan yang telah diuraikan pada bab sebelumnya, kesimpulan yang dapat diambil adalah sebagai berikut:

a. Rancangan komponen pengendalian intern sistem pemungutan pajak reklame yang diterapkan oleh BPPKAD Kabupaten Temanggung sudah berjalan dengan baik. Prosedur dilaksanakan oleh bagian-bagian yang terlibat sesuai dengan wewenang dan tanggung jawabnya. Terdapat empat jaringan prosedur yang membentuk sistem pemungutan pajak reklame yaitu prosedur pendaftaran dan pendataan wajib pajak, prosedur penetapan pajak, prosedur pembayaran dan pelaporan pajak, dan prosedur penagihan pajak.

b. Rancangan komponen pengendalian intern sistem pemungutan pajak reklame yang dijalankan oleh BPPKAD Kabupaten Temanggung telah sesuai dengan rancangan komponen pengendalian intern menurut Sistem Pengendalian Intern Pemerintah (SPIP), sudah memuat seluruh komponen pengendalian yang meliputi:

- Lingkungan pengendalian terlihat dari adanya peraturan yang ditetapkan oleh instansi, diperhatikannya kompetensi pegawai, adanya struktur organisasi, kepemimpinan yang kondusif, adanya pendelegasian wewenang dan tanggung jawab, adanya kebijakan tentang perekrutan dan pengembangan karir pegawai, dan adanya hubungan kerja yang baik dengan instansi pemerintah.

- Penilaian risiko terlihat dari adanya identifikasi, pengelolaan, dan evaluasi risiko. Hasil identifikasi risiko salah satu diantaranya adalah keterlambatan pembayaran pajak. Untuk mengatasi risiko tersebut yaitu dengan menerapkan sistem denda. 
- Kegiatan pengendalian terlihat dari adanya review kinerja, pembinaan sumber daya manusia, pengelolaan sistem informasi, pengendalian fisik aset, penetapan indikator kinerja, adanya sistem otorisasi, adanya pencatatan, dan dokumentasi atas pengendalian intern dan transaksi. Pada sub komponen pemisahan tugas masih terdapat rangkap jabatan. Sebagai contoh pegawai bidang pelayanan merangkap jabatan sebagai bendahara penerimaan, pegawai bidang pelayanan, pengelolaan data, dan penetapan pendapatan juga merangkap jabatan sebagai petugas penagihan.

- Informasi dan komunikasi terlihat dari adanya koordinasi antar bidang, sistem informasi yang terkomputerisasi, hubungan yang terjalin dengan baik antara pimpinan dengan pegawai pada tingkatan yang lebih rendah.

- Pemantauan terlihat dari adanya pemantauan yang dilakukan oleh pimpinan instansi, kepala bidang, Badan Pengawas Keuangan dan Pembangunan (BPKP), dan inspektorat kabupaten.

\section{DAFTAR PUSTAKA}

A. Hall, James. 2007. Sistem Informasi Akuntansi. Edisi 4, Buku 1. Terjemahan Dewi Fitriasari dan Deny amos Kwary. Jakarta : Salemba Empat.

Alek dan Achmad. 2011. Bahasa Indonesia untuk Perguruan Tinggi. Jakarta : Kencana

Arens, A. Alvin, Randal J. Elder dan Mark S. Beasley. 2008. Auditing dan Jasa Assurance, Edisi Keduabelas Jilid 1. Terjemahan Herman Wibowo. Jakarta : Erlangga

BPKP. 2009. Modul 1 : Gambaran Umum SPIP. Ciawi : Pusdiklatwas BPKP
Bungin, Burhan. 2013. Metodologi Penelitian Sosial dan Ekonomi. Jakarta : Kencana

Kabupaten Temanggung. Peraturan Daerah Kabupaten Temanggung Nomor 18 Tahun 2009 Tentang Pajak Reklame. Sekretariat Daerah. Temanggung

Kabupaten Temanggung. Peraturan Daerah Kabupaten Temanggung Nomor 33 Tahun 2011 Tentang Penyelenggaraan Reklame. Sekretariat Daerah. Temanggung

Kabupaten Temanggung. Rencana Strategi Badan Pendapatan, Pengelolaan Keuangan dan Aset Daerah Kabupaten Temanggung. Sekretariat Daerah. Temanggung

Kabupaten Temanggung. Struktur Organisasi Badan Pendapatan, Pengelolaan Keuangan dan Aset Daerah Kabupaten Temanggung. Sekretariat Daerah. Temanggung

Kabupaten Temanggung. Peraturan Daerah Kabupaten Temanggung Nomor 21 Tahun 2011 Tentang Organisasi dan Tata Kerja Dinas Daerah Kabupaten Temanggung. Sekretariat Daerah. Temanggung

Kabupaten Temanggung. Peraturan Bupati Temanggung Nomor 70 Tahun 2011 Tentang Penjabaran Tugas Pokok, Fungsi, dan Tata Kerja Dinas Pendapatan Pengelolaan Keuangan dan Aset Daerah Kabupaten Temanggung. Sekretariat Daerah. Temanggung

Krismiaji. 2010. Sistem Informasi Akuntansi. Yogyakarta: UPP STIM YKPN

Mardiasmo. 2011. Perpajakan. Yogyakarta: Andi Mulyadi. 2009. Auditing, Edisi 6 Buku 1. Jakarta : Salemba Empat 
Republik Indonesia. Peraturan Pemerintah Nomor 60 Tahun 2008 Tentang Sistem Pengendalian Intern Pemerintah. Sekretariat Negara. Jakarta

Republik Indonesia. Peraturan Pemerintah Nomor 1 Tahun 2004 Tentang Perbendaharaan Negara. Sekretariat Negara. Jakarta

Supardi. 2005. Metodologi Penelitian Ekonomi dan Bisnis. Yogyakarta : UII Press

Suwanda, Dadang. 2016. Sistem Pengendalian Intern Pemerintah.Yogyakarta : PPM Manajemen

Wijaya, Toni. 2013. Metodologi Penelitian Ekonomi dan Bisnis. Yogyakarta : Graha Ilmu 